\title{
Herbal and nutritional supplement use among college students in Qatar
}

R. Mamtani, ${ }^{1}$ S. Cheema, ${ }^{1}$ B. MacRae, ${ }^{2}$ H. Alrouh, ${ }^{1}$ T. Lopez, ${ }^{2}$ M. ElHajj ${ }^{3}$ and Z. Mahfoud ${ }^{1}$

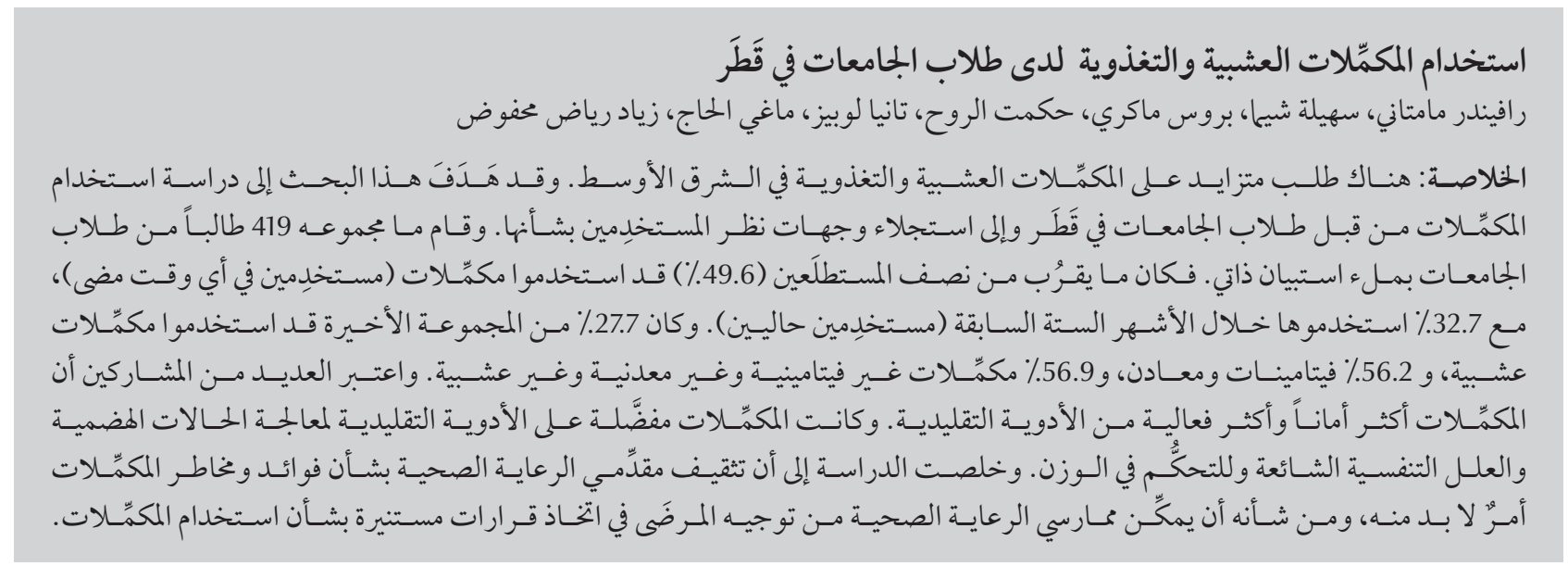

ABSTRACT There is increasing demand for herbal and nutritional supplements in the Middle East. This study aimed to examine the use of supplements by college students in Qatar and to elucidate users' views about them. A total of 419 college students completed a self-administered questionnaire. Almost half of the respondents (49.6\%) had used supplements (ever users), with 32.7\% reporting using them in the previous 6 months (current users). Of the latter, $27.7 \%$ had used herbal supplements, $56.2 \%$ vitamins and minerals and $56.9 \%$ non-vitamin, non-mineral, non-herbal supplements. Many participants considered supplements to be safer and more effective than conventional medicines. Supplements were preferred over conventional medicines for the treatment of digestive conditions and common respiratory ailments and for weight management. Educating health-care providers about the benefits and risks of supplements is imperative and will enable health-care practitioners to guide patients in making informed decisions about supplement use.

\section{Consommation de compléments nutritionnels et à base de plantes par des étudiants de l'enseignement} supérieur au Qatar

RÉSUMÉ La demande en compléments nutritionnels et à base de plantes est croissante au Moyen-Orient. La présente étude visait à examiner la consommation de compléments par des étudiants de l'enseignement supérieur au Qatar et à élucider le point de vue des utilisateurs en la matière. Au total, 419 étudiants ont rempli un autoquestionnaire. Près de la moitié des répondants $(49,6 \%)$ avaient déjà consommé des compléments au moins une fois dans leur vie, et 32,7\% indiquaient en avoir consommés au cours des six derniers mois. Parmi ceux-ci, 27,7\% avaient déjà consommé des compléments à base de plantes, 56,2\% avaient choisi des vitamines et des minéraux et $56,9 \%$ des compléments ne contenant ni vitamines, ni minéraux, ni plantes. De nombreux participants considéraient les compléments comme plus sûrs et plus efficaces que les médicaments conventionnels. Les compléments étaient préférés aux médicaments conventionnels pour le traitement des affections digestives, des maladies respiratoires courantes et pour le contrôle du poids. L'éducation d les prestataires de soins de santé aux risques et aux avantages des compléments est impérative et permettra aux praticiens de conseiller les patients pour qu'ils prennent des décisions éclairées en la matière.

'Weill Cornell Medical College in Qatar, Doha, Qatar(Correspondence to S. Cheema:soc2005@qatar-med.cornell.edu). ${ }^{2}$ College of the North Atlantic in Qatar, Doha, Qatar.

${ }^{3}$ Qatar University, Doha, Qatar

Received: 06/01/14; accepted: 11/03/14 


\section{Introduction}

The demand for herbal and nutritional supplements is high. Presently, around $80 \%$ of the world's population use herbal medicines (1-4), and nutritional supplement use is also common $(5,6)$. Evidence regarding the benefits and risks of supplements is becoming apparent (7). They are increasingly gaining acceptance and their sales have soared in recent years; in 2009 the global market was valued at $€ 45-50$ billion (8). An increased demand has been reported in the Middle East, particularly in the Gulf Cooperation Council (GCC) nations (9-12).

There have been some reports about supplement use among the general population and particularly by diabetic patients in Kuwait, Bahrain and Saudi Arabia $(10,13)$. Population-based data on supplement use among students, however, are scarce. A recent study from Palestine reported that herbal self-therapy was common among university students, but the study did not report on nutritional supplement use (14). Another study of athletes in Qatar reported that over $60 \%$ of respondents used vitamin supplements (15). Clearly further data on the effectiveness and safety of supplements is needed $(7,16,17)$. Such data could be instructive to help us develop evidence-based recommendations governing the use of supplements.

To contribute to this knowledge, we conducted a survey directed at college students in Doha, Qatar. The purpose of our study was to determine the extent of use of supplements among college students and to elucidate the views of students towards their use.

\section{Methods}

\section{Sampling}

A sample of 400 students were estimated to be sufficient to assess the prevalence of ever use of supplements to within a margin of error of 5\% with a $95 \%$ confidence interval. This sample size was estimated to be sufficient to detect differences between ever use and never use of at least 17\% (corresponding to an odds ratio of 2) with $90 \%$ power and a significance level of 5\% using the chi-squared test.

The study was carried out from April to June 2012. Representative samples of students from 2 colleges-Weill Cornell Medical College in Qatar and the College of the North Atlantic in Qatar-were obtained using stratified sampling. The students were stratified according to their year of study and nationality. Random samples proportional to the size of each stratum were drawn. Approval for this study was obtained from the institutional review boards of the colleges.

From the total student population $(n=2370), 508$ students were selected to participate in the study. Of the 508 students, 419 completed the questionnaire, representing a response rate of $82.4 \%$.

\section{Data collection}

We developed a self-administered questionnaire to obtain students' demographic information, details of supplements used and users' views regarding supplements versus conventional medicines. The 40-item questionnaire was adapted from a survey utilized in a previous study (18). We piloted the questionnaire on 6 students and circulated the feedback among the authors. Thereafter, minor language adjustments were made to the questionnaire to add clarity.

The questionnaire was distributed by the research staff and was completed voluntarily by the students in the classrooms of the respective colleges. Participants were asked if they had taken (yes/no) at least 1 nutritional or herbal supplement at some point in their life (defined as ever users) and then to list any supplements taken in the last 6 months (defined as current/ recent users). They were asked to respond by agreeing, disagreeing or stating that they had no opinion regarding statements related to the safety and effectiveness of supplements when compared with conventional prescription and non-prescription medicines. Students were also asked to select their preference between supplements and prescription/non-prescription medicines for treating various medical conditions.

The following definitions of herbal and nutritional supplements were included in the questionnaire to aid respondents in answering the questions $(19,20)$. No guidance or assistance was provided to the students as they completed the questionnaire. "Herbal and nutritional supplements are substances you eat or drink. They can be vitamins, minerals and herbs, or parts of these substances." "Herbal supplements are plants or plant parts used for their scent, flavour or therapeutic properties. Examples include Echinacea, ginseng and aloe." "Nutritional supplements refers to vitamins, minerals and other nutrients that are used to support health and treat illness. Examples include vitamins, fish oil and omega-3 fatty acids."

\section{Data analysis}

The respondents' demographic characteristics were summarized using frequency distributions. Associations between the students' ever use of supplements and their demographic and behavioural characteristics were assessed using the chi-squared test or Fisher exact test. The student's views about supplements versus prescription and non-prescription medications and their preferences towards each in treating various illnesses were summarized using frequency distributions.

Analyses were performed using IBM SPSS software, version 21. The significance level was set at $5 \%$. 


\section{Results}

\section{Demographic characteristics}

Table 1 shows the demographic characteristics of the respondents $(n=419)$; $79.3 \%$ were aged 24 years or younger, $40.4 \%$ were female, $46.2 \%$ were of Qatari nationality and $40.7 \%$ were in a college programme related to health care. Of all respondents, $82.8 \%$ rated their health as excellent or good.

\section{Supplement use}

Of the 419 students who completed the questionnaire, 208 (49.6\%) had used at least 1 nutritional or herbal supplement at some point in their life (95\% CI: 44.9\%-54.4\%). Sex was the only variable that correlated significantly with students' ever use of supplements; the proportion of students ever using supplements was higher in females $(56.5 \%)$ than in males (45.2\%) $(P=0.023)$. None of the other listed variables (age, marital status, nationality, year of college, health-related field of study or self-rated health) were significantly associated with supplement use. The top 2 reasons for using supplements reported by the respondents were that they were safe to use and they prevented sickness.

\section{Types of supplements}

A total of 137 students out of 419 (32.7\%) were current/recent users of supplements. For analysis the responses were divided into 3 main categories: herbal supplements; vitamins and minerals; and non-herbal, non-vitamin, non-mineral supplements. Of all current/recent users, 56.9\% had taken non-herbal, non-vitamin, non-mineral supplements (the most commonly used were proteins, fish oil and omega 3), 56.2\% vitamins and minerals (most commonly multivitamins, vitamin D and vitamin C) and $27.7 \%$ herbal supplements (most commonly ginger, mint and olive oil). Several respondents reported using more than one type of supplement.

\section{Respondents' perceived views on supplements}

Participants expressed confidence in the effectiveness and safety of supplements. In terms of safety, $58.5 \%$ agreed that supplements were safer than medicines, while $10.6 \%$ disagreed. Concerning effectiveness $42.2 \%$ agreed that supplements were more effective than medicines, whereas $17.9 \%$ disagreed.

\begin{tabular}{|c|c|c|c|c|c|c|}
\hline \multirow[t]{2}{*}{ Characteristic } & \multirow{2}{*}{$\begin{array}{c}\text { Total } \\
\text { No. }\end{array}$} & \multicolumn{2}{|c|}{ Ever-users } & \multicolumn{2}{|c|}{ Never-users } & \multirow[t]{2}{*}{$P$-value ${ }^{b}$} \\
\hline & & No. & $\%$ & No. & $\%$ & \\
\hline All & 419 & 208 & 49.6 & 211 & 50.4 & \\
\hline \multicolumn{7}{|l|}{ Age (years) } \\
\hline$\leq 24$ & 329 & 171 & 52.0 & 158 & 48.0 & 0.095 \\
\hline$\geq 25$ & 86 & 36 & 41.9 & 50 & 58.0 & \\
\hline \multicolumn{7}{|l|}{ Sex } \\
\hline Female & 168 & 95 & 56.5 & 73 & 43.5 & 0.023 \\
\hline Male & 248 & 112 & 45.2 & 136 & 54.8 & \\
\hline \multicolumn{7}{|l|}{ Marital status } \\
\hline Never married & 345 & 172 & 49.9 & 173 & 50.1 & 0.845 \\
\hline Ever married & 70 & 34 & 48.6 & 36 & 51.4 & \\
\hline \multicolumn{7}{|l|}{ Nationality } \\
\hline Qatari & 192 & 91 & 47.4 & 101 & 52.6 & 0.372 \\
\hline Non-Qatari & 224 & 116 & 51.8 & 108 & 48.2 & \\
\hline \multicolumn{7}{|c|}{ Health-related field of study } \\
\hline Yes & 169 & 81 & 47.9 & 88 & 52.1 & 0.620 \\
\hline No & 246 & 124 & 50.4 & 122 & 49.6 & \\
\hline \multicolumn{7}{|l|}{ Year in college } \\
\hline First year & 120 & 61 & 50.8 & 59 & 49.2 & 0.962 \\
\hline Second year & 140 & 69 & 49.3 & 71 & 50.7 & \\
\hline Third or more & 156 & 77 & 49.4 & 79 & 50.6 & \\
\hline \multicolumn{7}{|l|}{ Self-rated health } \\
\hline Excellent or good & 346 & 168 & 48.6 & 178 & 51.4 & 0.302 \\
\hline Fair or below & 72 & 40 & 55.6 & 32 & 44.4 & \\
\hline
\end{tabular}

${ }^{a}$ Number of students may not always add up to the total as some did not answer all the questions; ${ }^{b}$ Chi-squared or Fisher exact test, as appropriate. 


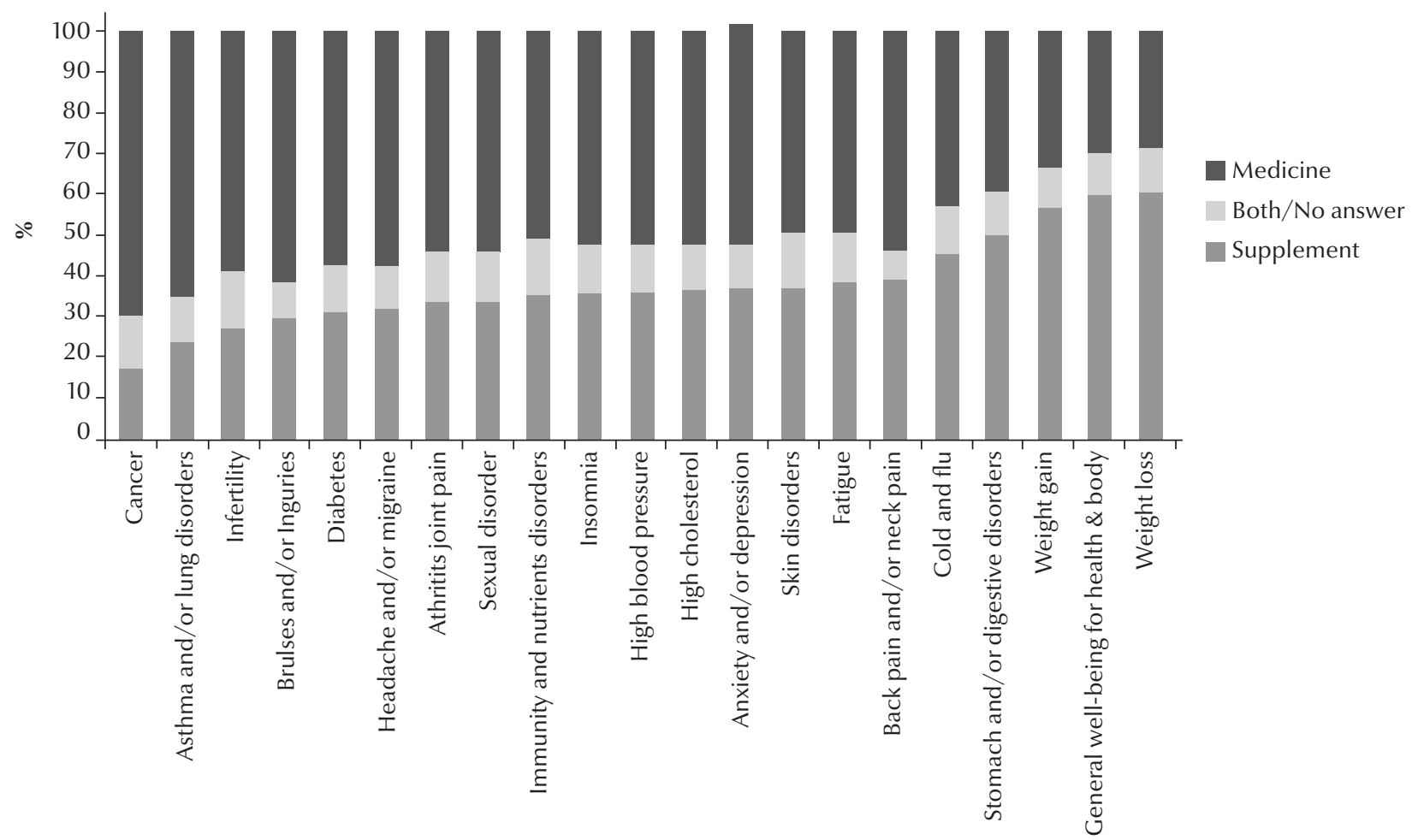

Figure 1 Students' choice of supplements versus medicines for treating various medical conditions and for promoting health $(n=208)$

Medicines were the most common first choice for treating most conditions (Figure 1). However, supplements were the preferred option for the treatment of conditions related to weight problems and common digestive and respiratory ailments. Preference for their use in treating conditions such as cancer and diabetes was notably lower.

\section{Discussion}

In this study in Qatar the proportion of college students who had ever used supplements was high (49.6\%). While supplements have beneficial health effects, their inappropriate use can result in adverse effects (7). Consulting a licensed health-care practitioner before using supplements is important.

Among the supplement users, multivitamins and proteins were commonly reported supplements. The finding about the use of protein supplements is of concern since they can cause adverse gastrointestinal effects such as stomach cramps and diarrhoea (21). Additionally, they have not been shown to have any beneficial effect on athletic performance and strength training $(22,23)$. Excessive use of multivitamins has also been reported to have negative health consequences (7).

Sex was the only demographic characteristic significantly associated with supplement use; females were more likely to have ever used herbal or nutritional supplements. This association with respondents' sex was observed in other studies on the general population in Saudi Arabia and the United States $(10,24)$, in addition to college students in Palestine (14). However, another study from the United States found no significant sex differences in use of non-herbal, nonvitamin, non-mineral supplements (25).

Most respondents had a favourable stance towards supplements; they had higher confidence in them and viewed them as both safer and more effective than prescription and non-prescription medicines. Most respondents favoured supplements over medicines for minor health concerns such as weight loss/gain and gastrointestinal disturbances. Whilst the majority of respondents favoured prescription and non-prescription medicines for the treatment of serious and potentially life-threatening conditions, a portion still favoured supplements for treating cancer, diabetes and high blood pressure. This is a highly concerning finding since these individuals might not seek conventional treatments of scientifically proven value.

In the WHO Eastern Mediterranean Region, particularly in the GCC nations where there has been a rapid industrial and economic growth, the demand for supplements is strong and likely to grow (9-12), due to increasing wealth, level of education, health awareness, prevalence of chronic conditions 
and associated use of alternative medicines $(2,24)$, media publicity and the availability of supplements through the Internet (26). Health practitioners in the region who do not possess the knowledge and skills to counsel patients on appropriate use of supplements $(27,28)$ could benefit from the findings of this study as well as training in this area.

Our study has several limitations. The estimates of supplement use were based on self-reported information and we were unable to validate the subjects' responses. Our study sample was limited to 2 colleges and therefore may not be representative of the nation's college population. Additionally, some examples of supplements (e.g. multivitamins and fish oil) were mentioned as examples in the survey questions and this may have had a suggestion bias effect on the responses.

\section{Conclusions}

As the evidence regarding the benefits and risks of supplements continues to emerge, it is imperative to develop evidence-based national guidelines on how best to incorporate this aspect of medical care into the health-care delivery systems in Qatar. Additionally, all healthcare practitioners and students should be educated in this discipline so that they are prepared to engage in meaningful discussions with patients to help them make informed decisions about the use of supplements. Furthermore, creating public awareness regarding the appropriate use of supplements is essential.
Acknowledgements

We would like to acknowledge Albert Lowenfels for his guidance on preparation of the manuscript, and to Paul Rutter for sharing the original survey from his study. Additionally, we acknowledge Norman Wong and Wisal Salih, for their contribution in administering the survey, Sura Al-Samraye, Nneka Onwuachu and Mariyam Mohammed and Basma Tawfiq for data collection and data input.

Funding: This work was funded by both the Qatar Foundation through the Weill Cornell Medical College in Qatar Biomedical Research Program and by the SEED Program at the College of the North Atlantic - Qatar (CNA-Q).

Competing interests: None declared.

\section{References}

1. Zhang X. WHO traditional medicine strategy 2002-2005. Geneva: World Health Organization; 2002 (WHO/EDM/ TRM/2002.1).

2. Eisenberg DM, Davis RB, Ettner SL, Appel S, Wilkey S, Van Rompay $M$, et al. Trends in alternative medicine use in the United States, 1990-1997: results of a follow-up national survey. JAMA. 1998 Nov 11;280(18):1569-75. PMID:9820257

3. Rafferty AP, McGee HB, Miller CE, Reyes M. Prevalence of complementary and alternative medicine use: state-specific estimates from the 2001 Behavioral Risk Factor Surveillance System. Am J Public Health. 2002 Oct;92(10):1598-600. PMID:12356602

4. Abu-Irmaileh BE, Afifi FU. Herbal medicine in Jordan with special emphasis on commonly used herbs. J Ethnopharmacol. 2003 Dec;89(2-3):193-7. PMID:14611882

5. Foote JA, Murphy SP, Wilkens LR, Hankin JH, Henderson $\mathrm{BE}$, Kolonel LN. Factors associated with dietary supplement use among healthy adults of five ethnicities: the Multiethnic Cohort Study. Am J Epidemiol. 2003 May 15;157(10):888-97. PMID:12746241

6. Archer SL, Stamler J, Moag-Stahlberg A, Van Horn L, Garside D, Chan Q, et al. Association of dietary supplement use with specific micronutrient intakes among middle-aged American men and women: the INTERMAP Study. J Am Diet Assoc. 2005 Jul;105(7):1106-14. PMID:15983530

7. Ernst E, Pittler MH, Wider B. The desktop guide to complementary and alternative medicine. 2nd ed. London: Mosby Elsevier; 2006.

8. Nicoletti M. Nutraceuticals and botanicals: overview and perspectives. Int J Food Sci Nutr. 2012 Mar;63 Suppl 1:2-6. PMID:22360273

9. GCC pharmaceutical industry report 2013. Dubai, United Arab Emirates: Alpen Capital; 2013 (http://www.alpencapital.com/media-reports-2013.htm, accessed 18 November 2014).
10. Al-Faris EA, Al-Rowais N, Mohamed AG, Al-Rukban MO, AlKurdi A, Balla Al-Noor MA, et al. Prevalence and pattern of alternative medicine use: the results of a household survey. Ann Saudi Med. 2008 Jan-Feb;28(1):4-10. PMID:18299652

11. Al Shaar IA, Ismail MF, Yousuf WA, Salama RE. Knowledge, attitudes and practice of general practitioners towards complementary and alternative medicine in Doha, Qatar. East Mediterr Health J. 2010 May;16(5):522-7.PMID:20799552

12. Mathew E, Muttappallymyalil J, Sreedharan J, John Lj, John J, Mehboob M, et al. Self-reported use of complementary and alternative medicine among the health care consumers at a tertiary care center in Ajman, United Arab Emirates. Ann Med Health Sci Res. 2013 Apr;3(2):215-9. PMID:23919193

13. Khalaf AJ, Whitford DL. The use of complementary and alternative medicine by patients with diabetes mellitus in Bahrain: a cross-sectional study. BMC Complement Altern Med. 2010;10(1):35. PMID:20630070

14. Sawalha AF, Sweileh WM, Zyoud SH, Jabi SW. Self-therapy practices among university students in Palestine: focus on herbal remedies. Complement Ther Med. 2008 Dec;16(6):343-9. PMID:19028335

15. Knez WL, Peake JM. The prevalence of vitamin supplementation in ultraendurance triathletes. Int J Sport Nutr Exerc Metab. 2010 Dec;20(6):507-14. PMID:21116023

16. Vickers AJ, Cassileth BR. Unconventional therapies for cancer and cancer-related symptoms. Lancet Oncol. 2001 Apr;2(4):226-32. PMID:11905768

17. Marik PE, Flemmer M. Do dietary supplements have beneficial health effects in industrialized nations: what is the evidence? JPEN J Parenter Enteral Nutr. 2012 Mar;36(2):159-68. PMID:22275325

18. AlBraik FA, Rutter PM, Brown D. A cross-sectional survey of herbal remedy taking by United Arab Emirate (UAE) citizens in Abu Dhabi. Pharmacoepidemiol Drug Saf. 2008 Jul;17(7):72532. PMID:18395880 
19. Dietary supplements (herbal medicines and natural products) [Internet]. New York: WebMD; 2013 (http://www.webmd. $\mathrm{com} / \mathrm{diet} /$ dietary-supplements-herbal-medicines-and-natural-products, accessed 18 November 2014).

20. Dietary and herbal supplements [Internet]. Maryland: National Center for Complementary and Alternative Medicine; 2013 (http://nccam.nih.gov/health/supplements/, accessed 15 October 2014).

21. Clarkson PM. Nutritional supplements for weight gain. Sports Science Exchange. 1998;11(1):68.

22. Abel T, Knechtle B, Perret C, Eser P, von Arx P, Knecht H. Influence of chronic supplementation of arginine aspartate in endurance athletes on performance and substrate metabolism-a randomized, double-blind, placebo-controlled study. Int J Sports Med. 2005 Jun;26(5):344-9. PMID:15895316

23. Williams AG, van den Oord M, Sharma A, Jones DA. Is glucose/amino acid supplementation after exercise an aid to strength training? Br J Sports Med. 2001 Apr;35(2):109-13. PMID:11273972

24. Timbo BB, Ross MP, McCarthy PV, Lin CT. Dietary supplements in a national survey: Prevalence of use and reports of adverse events. J Am Diet Assoc. 2006 Dec;106(12):1966-74. PMID:17126626

25. Newberry H, Beerman K, Duncan S, McGuire M, Hillers V. Use of nonvitamin, nonmineral dietary supplements among college students. J Am Coll Health. 2001 Nov;50(3):123-9. PMID:11765248

26. Global operations [Internet]. India: Plethico Pharmaceuticals; 2011 (http://www.plethico.com/new/operations/globaloperations.html, accessed 6 May 2014)

27. Khader Y, Sawair FA, Ayoub A, Ayoub N, Burgan SZ, Amarin Z. Knowledge and attitudes of lay public, pharmacists, and physicians toward the use of herbal products in North Jordan. J Altern Complement Med. 2008 Dec;14(10):1186-7. PMID:19040389

28. Al SI, Ismail MF, Yousuf WA, Salama RE. Knowledge, attitudes and practice of general practitioners towards complementary and alternative medicine in Doha, Qatar. East Mediterr Health J. 2010 May;16(5):522-7. PMID:20799552 